\title{
СТАНОВЛЕННЯ ТА РОЗВИТОК ВІДПОВІДАЛЬНОСТІ ЗА РОЗБІЙ У КРИМІНАЛЬНОМУ ЗАКОНОДАВСТВІ УКРАЇНИ
}

\author{
СЕМЕНИШИН Микола Олександрович - кандидат юридичних наук, \\ докторант Донецького юридичного інституту МВС України
}

DOI:10.32782/EP.2020.1.19

УДК 343.3/7.341

\begin{abstract}
У статті на основі аналізу історичних документів, нормативно-правових актів та практики діяльності виділено періоди розвитку кримінальноӥ відповідальності за розбій за критерієм законодавчого закріплення изього поняття. Грунтуючись на результатах вивчення різноманітних підходів до розуміння поняття корисливої насильницької злочинності цे науково-теоретичного осмислення проблеми посягання на право власності й життя та здоров'я особи та їм запобігання, а також зважаючи на актуальність иієї проблематики, обгрунтовуеться необхідність визнання дослідження проблем запобігання розбійним нападам як самостійного спечіально-кримінологічного напряму.

Ключові слова: генеза, власність, розбій, чуже майно, напад, насильство кримінальна відповідальність.
\end{abstract}

Серед різних форм злочинних посягань на захищені кримінальним законом блага, цінності та інші сфери життєдіяльності людей розбій $\epsilon$ одним із найнебезпечніших злочинів. Це зумовлено тим, що при розбої посягання на основний об'єкт здійснюється шляхом посягання на особу, тоді як, відповідно до ст. 3 Конституції України, людина, iї життя і здоров'я, честь і гідність, недоторканність i безпека визнаються найвищою соціальною цінністю, а утвердження i забезпечення прав і свобод людини є головним обов'язком держави. У реалізації цього обов'язку провідна роль належить право- охоронним органам взагалі та органам внутрішніх справ, зокрема. Тому вдосконалення правоохоронної діяльності як реальні кроки з гарантування прав і свобод людини передбачає застосування різнобічних заходів. Одним із пріоритетних заходів 6 вдосконалення кримінально-правового захисту людини від найбільш небезпечних злочинів, до яких, у першу чергу, слід віднести такий злочин, як розбій.

Розбій як об'єкт кримінально-правового та кримінологічного вивчення, який попадає у поле зору суспільства, піддається дослідженню досить давно. Ще стародавні філософи Платон і Аристотель цікавились проблемами злочинів, їх причинами та покаранням за них. Сьогодні не варто забувати історичні здобутки, оскільки чинний Кримінальний кодекс України грунтується на історичному досвіді розвитку кримінально-правових та кримінологічних досліджень, зокрема, які обгрунтовували зміст його окремих інститутів і розділів.

Формуванню кримінально-правових норм, виробленню конкретних дефініцій та їх розміщенню в Особливій частині Кримінального кодексу передував тривалий період розвитку правової думки, що позначився на історії становлення національної правової системи. Тому поняття, систему й окремі види злочинів проти власності неможливо правильно оцінити без звертання до історичних першоджерел права.

Протягом століть тривав поступальний розвиток норм про відповідальність за злочи- 
ни проти власності, зокрема за розбій. Відомі пам'ятки законодавства, що діяли на території України, не використовували такої категоpiï, як «розбій». В історичних пам'ятках згадуються терміни «красти», «украсти», «татьба», які певним чином відповідали сучасному поняттю «викрадення». Мабуть, першою кримінально-правовою нормою, що регулювала відповідальність за викрадення чужого майна, була ст. 6 договору руських з греками при князі Олегові 911 р. (за Іпатіївським списком [1, с. 4].

I хоча в цьому договорі не вжито такого терміну, як «розбій», на думку I. Ф. Реверса (1826 р.), договір князя Олега 911 р. виокремлював такий вид татьби, як явне відбирання чужої речі (розбій) [2, с. 4].

Основним давньоруським джерелом світського писаного права в літературі вважається «Руська правда». Це джерело містить норми різного характеру, зокрема кримінальноправового. «Руська Правда» трактує злочин як «образу». Поряд зі злочинами проти особистості в ній згадуються майнові злочини: розбій (відмежування якого від грабежу не було), крадіжка («татьба»), самовільне користування чужим майном тощо (ст. 33, 35, 37, 40) [3, с. 229-231].

У «Руській правді» про розбій згадується як про найнебезпечніший злочин, однак визначення цього злочину в законі немає. При цьому самостійно термін «розбій» не використовується, а йдеться про вбивство в розбої, яке визнається більш небезпечним, ніж звичайне вбивство, тому за вбивство в розбої передбачалося більш суворе покарання[4, с. 59; 5, с. 208-209].

у період феодальної роздробленості Русі найбільш відомим джерелом, що містить норми кримінально-правового характеру, вважається Псковська Судова грамота (1397-1467 рр.), що встановлювала норми кримінального права та діяла на території Московії, уже розрізняла 3 татьби крадіжку, грабіж, розбій та «наход» (ст. 1, 7, 20, 34) [4, c. 331-332].

Необхідно відмітити, що в пам'ятках XV ст. термін «розбій» зберіг значення неспровокованого вбивства 3 метою розбою або озброєної засідки на шляхах 3 цією ж метою.
У другій половині XIV ст. навколо Московського князівства починають об'єднуватися руські землі. До основних документів того періоду, що містить норми кримінального права, належать Судебник 1497 і 1550 рр. та Соборне Укладення 1649 р. «Великокняжий» Судебник 1497 р. в літературі іменується першим загальноросійським. У ньому не багато норм кримінального права, однак серед злочинів особливо виділяються майнові, до яких належать, насамперед, розбій і татьба (ст. 8, 10, 14, 34, 39) [6, с. 54].

Судебники 1497 і 1550 р. [6, с. 55, 108] та Статути Великого князівства Аитовського 1566 і 1588 р. [7, с. 8] також містять термін «розбій», але не визначають ознаки цього злочину.

Після приєднання частини України до Московської держави в 1654 р. на території Гетьманщини, Аівобережжя набула поширення дія Соборного Уложення 1649 р., яке не тільки передбачало відповідальність за розбій, а й встановлювало його види - простий та кваліфікований.

На відміну від попереднього законодавства, що пов'язало розбій, звичайно, з убивством, Соборне Уложення виокремлює розбій з обтяжуючими обставинами і без таких [8, с. 415]. Разом з тим, час звертає на себе увагу певна нечіткість та невизначеність категорії «розбій» у статтях Соборного Уложення 1649 р., що викликало потребу у прийнятті нових законів.

Тривалий час (1743-1840рр.) на території Аівобережної України був чинним Закон під назвою «Права, за якими судиться малоросійський народ». Цей Закон не тільки розмежовував між собою крадіжку, грабіж та розбій, а й встановлював покарання у главі 22 «О грабежах, разных шкодах и за это о наказаниях» за різні види викрадення. Так, Артикул 1 передбачав страту за «воровство с поличным или без поличного, если кража выше 20 рублей», а для злодіїв, які «... крадуть разные вещи и явно похиша, убъгають...», артикул передбачав покарання у вигляді «бить розгами или плетьми» [9, с. 430].

Аише в Уложенні про покарання кримінальні та виправні від 15 серпня 1845 р. мали місце чіткі та досконалі визначення багатьох видів злочинів, які актуальні і по теперішній 


\section{Кримінальне право, кримінальний процес та криміналістика}

час, у тому числі щодо таких категорій, як розбій, грабіж, крадіжка тощо [10]. Склади злочинів, які передбачали відповідальність за розбій, були сконцентровані у Відділі I «Про розбій» Глави III «Про викрадення чужого майна» Розділу XII «Про злочини та провини проти власності приватних осіб».

У Відділі I «Про розбій», який у ст. ст. 21292138 передбачав відповідальність за різні види розбійних діянь, при цьому в ст. 2129 містилося загальне визначення розбою, а в інших статтях цього відділу встановлювалася відповідальність за конкретні різновиди розбою [10, с. 297].

31 травня 1846 р. на території Російської імперії набув чинності новий Кримінальний кодекс під назвою «Ухвала про покарання кримінальних та виправних», що діяв зі змінами аж до соціалістичної революції 1917 р. Укладення про покарання кримінальні та виправні від 1845 р. передбачало відповідальність за розбій. Так, розбій, згідно з цим Законом, становить, по-перше, відбирання майна із застосуванням насильства, що було небезпечним для життя чи здоров'я, або свободи, або з погрозою, по-друге, відкрите викрадення майна в присутності власника або інших осіб (ст. 2139). На відміну від Укладення 1845 р., Укладення 1903 р. не використовувало терміна «розбій». Проте відповідальність за його вчинення була передбачена (ст. 258 глави XXXII «О воровстве, разбое и вымогательстве»). Таємне або відкрите викрадення чужого майна 3 метою присвоєння охоплювалося єдиним поняттям «воровство» [6, с. 155].

У Кримінальному Уложенні 1903 р. [11] у межах одних складів злочинів були об'єднані злочини проти майна і доходів казни, а також проти власності приватних осіб. Цей закон піддав певному перегляду поняття «викрадення майна» взагалі і «розбій», зокрема. [11, с. 48].

Поняття розбою визначалося в ч. 1ст. 589 Кримінального Уложення як викрадення чужого рухомого майна $з$ метою привласнення за допомогою приведення у несвідомий стан, тілесного ушкодження, насильства над особою чи кримінальної погрози [11, с. 49]. Тобто межі категорії «розбій» за рахунок такого визначення значно розширювалися, бо цим визначенням охоплювалися і ознаки грабежу, поєднаного 3 насильством [11, с. 51-52].

На відміну від попереднього Уложення, в якому кваліфіковані види розбою передбачалися у різних статтях, Кримінальне Уложення 1903 р. всі кваліфіковані види розбою передбачає в ч. 2 ст. 589, яка містить 7 пунктів, а саме: 1) заподіяння вельми тяжкого або тяжкого тілесного ушкодження; 2) вчинення розбою в церкві; 3) вчинення у відкритому морі; 4) кількома особами, які вторгнулися для цього у заселений будинок або приміщення; 5) особою, яка запаслася зброєю або знаряддям для нападу або захисту; 6) зграєю; 7) особою, яка не менше трьох разів відбувала покарання за «воровство», розбій, вимагання або шахрайство і при цьому до закінчення п'ятирічного строку 3 дня відбування покарання за будь-яке 3 цих злочинних діянь [11, с. 58].

У цей період часу у кримінально-правовій доктрині терміни «власність» й «майно» вживалися найчастіше як синоніми і позначали всю сукупність майнових прав та інтересів. Можливо, тому I. Я. Фойницький об'єктом майнових посягань визнавав майно як «конкретний предмет юридичного панування людини як одну з частин його правової сфери» [3].

Кримінальний кодекс Української Соціалістичної Радянської Республіки від 23 серпня 1922 р. визначив розбій як відкритий 3 метою викрадення майна напад окремої особи на будь-кого, поєднаний з фізичним або психічним насильством, що загрожує смертю або каліцтвом (ч. 1 ст. 184 Кримінальний кодекс Української Соціалістичної Радянської Республіки). У ч. 2 ст. 184 КК УСРР такий самий злочин, вчинений групою осіб (бандитизм), карається - покараннями, передбаченими ст. 76 Кримінального Кодексу[12, с. 58-59].

Мало чим відрізняючись один від одного, перші радянські кримінальні кодекси України 1922 і 1926 рр., які сприйняли ідею Кримінального уложення про єдину кримінально-правову охорону державного, громадського та особистого (приватного) майна, розподіли злочини проти власності на розбої та інші посягання. 
Найбільш істотною відмітною особливістю Кримінального кодексу України 1960 р. було те, що він тривалий час розрізняв посягання на соціалістичне (державне, колективне) та індивідуальне майно громадян. Кримінальний кодекс Української Радянської Соціалістичної Республіки, прийнятий у 1960 р., передбачив відповідальність за розбій у двох статтях: ст. 86 Кримінального кодексу «Розбій з метою розкрадання державного або колективного майна» та ст. 142 Кримінального кодексу «Розбій» [13]. Диспозиції вказаних норм визначали розбій як напад з метою заволодіння державним або колективним майном, поєднаний з насильством, небезпечним для життя чи здоров'я особи, яка зазнала нападу, або з погрозою застосування такого насильства (ст. 86 Кримінального кодексу) та напад $з$ метою заволодіння індивідуальним майном громадян, поєднаний з насильством, небезпечним для життя чи здоров'я особи, яка зазнала нападу, або з погрозою застосування такого насильства (ст. 142 Кримінального кодексу). Отже, загальною ознакою розбою було відкрите викрадення чужого майна поєднаного з насильством, що є небезпечним для життя та здоров'я потерпілого.

Відповідно до КК УРСР 1960 р. розбій $з$ метою заволодіння соціалістичним майном вперше виділяється як самостійний склад злочину, який охоплюеться загальним поняттям «розкрадання», бо до цього розбій 3 метою заволодіння соціалістичним майном не був прямо передбачений у законодавстві, а розглядався у судовій практиці лише як кваліфікуюча ознака розкрадання.

Чинний Кримінальний кодекс України, прийнятий 5 квітня 2001 р., визначив розбій як напад 3 метою заволодіння чужим майном, поєднаний із насильством, небезпечним для життя чи здоров'я особи, яка зазнала нападу, або з погрозою застосування такого насильства (ст. 187 Кримінального кодексу України). Частина 2 статті 187 передбачає розбій, вчинений за попередньою змовою групою осіб або особою, яка раніше вчинила розбій або бандитизм, а частина 3 цієї статті розбій, поєднаний із проникненням у житло, інше приміщення чи сховище.

Розбій, спрямований на заволодіння майном у великих чи особливо великих розмірах або вчинений організованою групою, або поєднаний із заподіянням тяжких тілесних ушкоджень, кваліфікується за ч. 4 ст. 187 КК України [14].

Розбій належить до найбільш небезпечних корисливо-насильницьких злочинів. Він посягає на два об'єкти:

1)право власності;

2)особу (їі здоров'я і життя) [15, с. 177].

Водночас не менше значення приділяє кримінологія і поняттю розбою як окремого факту злочинної поведінки, що утворює сукупність розбоїв. Але, на відміну від кримінального права, що наводить правове поняття розбою, для кримінології цей феномен представляє значення лише як виявлення в ньому ознак, що характеризують не лише поодинокий факт діяння, а відображає закономірності цього явища загалом. Наприклад, кримінологія вивчає не розбій на банківські установи та інкасаторів, 3 метою встановлення у даному факті ознак складу злочину, передбаченого ст. 187 Кримінального кодексу України, а розбійні напади як явище та розповсюдження їх у регіоні (загальної кількості, рівня цих злочинів, зважаючи на певну кількість населення, динаміку їх вчинення за певні відрізки часу, частку в загальній кількості вчинених злочинів, розмір завданого збитку тощо), причин й умов учинення даних злочинів, характеристик особи, яка вчиняє розбій, особливостей протидії вищезазначеним злочинам.

Звичайно, без вивчення поодиноких фактів розбоїв на банківські установи та інкасаторів неможливо вивчити його системність, тому тісний зв'язок між окремими розбоями й сукупністю розбоїв підкреслює їх єдину кримінологічну сутність. Завжди існували й існують нині правові та соціальні аспекти розбою, однак останні пов'язані з виявленням того визначального загального, що лежить в основі співвідношення розбою й системи ïх вчинення. Тому кримінологія, вивчаючи розбій, аналізуючи психологічний аспект людської дії, поєднує його із соціологічним аспектом: переходить від індивідуальних учинків до масових, сукупності, до сутності суспільних відносин. У зв'язку з особою, яка вчинила розбій, розгляду підлягають і причини та умови злочину, злочинної поведінки 


\section{Кримінальне право, кримінальний процес та криміналістика}

особи для профілактики антигромадської поведінки, зокрема злочинної.

Кримінологія, вивчаючи суспільну небезпеку розбою, не перебуває осторонь від того, що визнається ним, а що таким не $є$.

Аналіз історичних документів дозволяє стверджувати, що формуванню кримінально-правових норм, що регулюють відповідальність за розбій, виробленню конкретних дефініцій передував досить тривалий період розвитку правової думки, який позначився на всій історії становлення української державності. Протягом століть відбувався поступальний розвиток норм про відповідальність за розбій.

3 огляду на викладене вище, можна виділити та охарактеризувати п'ять основних періодів формування кримінально-правової норми та вироблення конкретної дефініції розбою як об'єкта кримінологічного дослідження:

- перший період з 911 р. - до II пол. XIV ст. характеризується відсутністю чіткого терміну «розбій», але виокремленням виду татьби - явне відбирання чужої речі (розбій); другий період - II пол. XIV ст. 1846 р. характеризується слабким (або першою спробою) виділенням дефініції розбою та відокремленням його від татьби та грабежу. Також виокремлено різні види розбою, які перепліталися 3 ознаками татьби, встановлено покарання за розбій, яке було більш суворішим за татьбу;

третій період - 1846 р. - 1917 р. характеризується трьома фактами: 1) введенням у дію першого Кримінального кодексу в Російській імперії (Уложення про покарання кримінальні та виправні), у якому виділявся розбій як, по-перше, відбирання майна iз застосуванням насильства, що було небезпечним для життя чи здоров'я, або свободи, або з погрозою, по-друге, відкрите викрадення майна в присутності власника або інших осіб; 2) передбачено відповідальність за розбій, зокрема у Відділі I «Про розбій» Глави III «Про викрадення чужого майна» Розділу XII «Про злочини та провини проти власності приватних осіб»; 3) використання терміну «розбій» в Уложенні про покарання кримінальні та виправні від 1903 р., яке відмінило попереднє, проте відповідальність за його вчинення була передбачена, а таємне або відкрите викрадення чужого майна з метою присвоєння охоплювалося єдиним поняттям «воровство»;

- $\quad$ четвертий період - 1917 р. - 1990 р. характеризувався чотирма фактами: 1) встановленим жорстким покаранням за розбій, зокрема постанова ВЦВК «Про вилучення із загальної підсудності у місцевостях, оголошених на воєнному становищі» від 20 червня 1919 р. встановлювала право безпосередньої розправи аж до розстрілу за контрреволюційні злочини, до яких належав i розбій;2) визначенням розбою як відкритого 3 метою викрадення майна нападу окремої особи на будь-кого, поєднаного з фізичним або психічним насильством, що загрожує смертю або каліцтвом. Подальше редагування цієї дефініції відображено в Кримінальному кодексі Української Соціалістичної Радянської Республіки, що визначав розбій як відкритий 3 метою викрадення майна напад окремої особи на будь-кого, поєднаний з фізичним або психічним насильством, що загрожує смертю або каліцтвом (ст. 184 Кримінального кодексу УСРР); 3) визначення розбою як відкритого нападу окремої особи було дано спочатку і в ст. 174 КК 1927 року, а потім Постановою ВУЦВК і РНК УСРР від 15 березня 1930 р. внесено відповідні зміни та доповнення до ст. 174 КК 1927 р. та передбачено у ч. 2 ст. 174 КК таку кваліфікуючу ознаку розбою, як вчинення розбою групою осіб; 4) передбаченням Кримінальним кодексом УРСР 1960 р. відповідальності за розбій у двох статтях:ст. 86 КК, що передбачала відповідальність за розбій з метою розкрадання соціалістичного майна, і ст. 142 КК, що передбачала відповідальність за розбій з метою заволодіння особистим майном громадян, які були розташовані відповідно у главах II та V Особливої частини КК;

- $\quad$ п’ятий період з 1990 р. і до сьогодні характеризується змінами у правовому регулюванні форм власності в Україні. Так, поняття розбою у ст. 86 та 142 Кримінального кодексу УРСР змінилося словосполученнями «суспільне майно» та «особисте майно», «колективне майно» та «індивідуальне майно», а отже, чинний Кримінальний кодекс України визначив розбій як напад 3 
метою заволодіння чужим майном, поєднаний із насильством, небезпечним для життя чи здоров’я особи, яка зазнала нападу, або з погрозою застосування такого насильства (ст. 187 Кримінального кодексу України) й окреслив його кваліфікуючі ознаки, зокрема: а) за попередньою змовою групою осіб або особою, яка раніше вчинила розбій або бандитизм, є кваліфікуючою ознакою розбою (ч. 2 ст. 187 Кримінального кодексу України); б) проникнення в житло, інше приміщення чи сховище або спричинення значної шкоди потерпілому є кваліфікуючою ознакою розбою (ч. 3 ст. 187 Кримінального кодексу України); в) заволодіння майном у великих чи особливо великих розмірах, або вчинений організованою групою, або поєднаний із заподіянням тяжких тілесних ушкоджень є особливо кваліфікуючою ознакою (ч. 4 ст. 187 Кримінального кодексу України).

Щодо світового розвитку кримінальної відповідальності за розбій, то спочатку він був споріднений з крадіжкою та не відмежовувався від неї (П'ятикнижжя Мойсея), а вже у Вавилонській державі широко трактувався в законах царя Хаммурапі, які ефективно застосовувались на практиці. У становленні розбою як злочину проти власності значний крок вперед зробили юристи римського права (Закони XII таблиць), в якому спостерігається диференціація кримінальної відповідальності залежно від суб'єкта злочину - неповнолітня особа чи повнолітня. Подальший розвиток норм про кримінальну відповідальність за розбій відбувався під впливом національних культур, політичних подій у державах тощо.

\section{入iтepaтура}

1. Горішній О. О. Кримінально-правова характеристика розбою: автореф. дис.... канд. юрид. наук: 12.00 .08 «Кримінальне право та кримінологія; кримінально-виконавче право». Харків, 2010. 20 с.

2. Хрестоматия по истории русского права / сост. М. Ф. Владимирский-Буданов. 4-е изд. Киев: тип. Императорского ун-таСв. Владимира, 1968. Вып. 4. 239 с.

3. Фойницкий И. Я. Курс уголовного права. Часть Особенная: Посягательства личные и имущественные / под ред. А. А. Жижиленко. 7-е изд., доп. и пересмотр. СПб., 1977. 446 c.

4. Российское законодательство X-XX веков: в 9 т. Москва: Юрид. лит., 1984. Т. 1 : Законодательство Древней Руси. 1984. 432 с.

5. Гальперин С. И. Очерки первобытного права. СПб., 1993. 299 с.

6. Российское законодательство X-XX веков : в 9 т. Москва: Юрид. лит., 1984. Т. 2: Законодательство периода образования и укрепления Русского централизованного государства. 1985. 520 с.

7. Паламарчук К. В. Кримінально-правова характеристика розбою: автореф. дис.... канд. юрид. наук: 12.00 .08 «Кримінальне право та кримінологія; кримінально-виконавче право». Київ, 2017. 20 с..

8. Российское законодательство X-XX веков: в 9 т. Москва: Юрид. лит., 1984. Т. 3: Акты земских соборов. 1985. 512 с.

9. Права, за якими судиться малоросійський народ. 1743: Законодавство / ред. кол. О. М. Мироненко, К. А. Вислобоков,І. Б. Усенко та ін.; відп. ред. Ю. С. Шемчушенко. Київ: Ін Юре, 1997. 340 с.

10. Сказко Ю. А. Історико-правова генеза кримінальної відповідальності за розбійні напади на банківські установи та інкасаторів. Держава і право. 2017. № 77. С. 294-305.

11. Емельянов В. П. Защита права собственности уголовным законодательством. Харьков: Рубикон, 1996. 128 с.

12. Матышевский П. С. Преступления против собственности и смежные с ними преступления. Киев: Юринком, 1996. 240 с.

13. Кримінальний кодекс України : затв. Законом УРСР від 28 груд. 1960 р. Відомості Верховної Ради УРСР. 1961. № 2. Ст. 14.

14. Кримінальний кодекс України від 5 квіт. 2001 р. Верховна Рада України. URL: http://zakon3.rada.gov.ua/laws/show/2341-14.

15. Кримінальне право України. Особлива частина: підручник / Бажанов М. I., Баулін Ю. В., Борисов В. І. та ін.; за ред. проф.М. І. Бажанова, В. В. Сташиса, В. Я. Тація. 2-ге вид., перероб. і доп. Київ: Юрінком Інтер, 2004. 544 c. 


\section{АНОТАЦІЯ}

У статті на основі аналізу історичних документів, нормативно-правових актів та практики діяльності виділено періоди розвитку кримінальної відповідальності за розбій за критерієм законодавчого закріплення иъого поняття.

Аналіз історичних документів, які передбачали відповідальність за вчинення розбою, засвідчив про далеке минуле извого злочину, хоча саме поняття «розбій» виникло приблизно у X cm., через що запропонований автором історичний відлік розпочинається саме з ијєї дати. Окреслено наступні умовні періоди розвитку кримінальної відповідальності за розбій: 1) становлення кримінальної відповідальності за розбій та віднесення його до злочинів проти власності (911 p. - I пол. XVI cm.); 2) нормативного вдосконалення кримінальної відповідальності за розбій (II пол. XVI cm. - 1917 р.); 3) деталізаиї норм кримінальної відповідальності за розбій (1917 - 1990 рр.); 4) сучасний період розвитку кримінальної відповідальності за розбій (1990 p. - наш час). Для періодизачй історичного розвитку автором був обраний критерій законодавчого закріплення поняття «розбій», адже констатувати певні факти дозволяе лише вивчення та всебічний аналіз обічійних письмових джерел інформащиі, якими є історичні правничі документи. У иілому вся історія розвитку відповідальності за розбій - це прогресивний та результативний шлях від розбою як злочину проти особи, суміжного з убивством, до розбою як одного з найнебезпечніших злочинів проти власності, який посягає на відносини власності. На сучасному етапі розвитку Украӥнсъкої держави існує низка проєктів законів щодо внесення змін до ст. 187 КК Украӥни, які поки що перебувають на стадії обговорення та доопрацювання законодавчим органом Украӥни.

Грунтугчись на результатах вивчення різноманітних підходів до розуміння поняття корисливої насильницької злочинності й науковотеоретичного осмислення проблеми посягання на право власності й життя та здоров'я особи, та їм запобігання, а також зважаючи на актуальність иієї проблематики, обгрунтовується необхідність визнання дослідження проблем запобігання розбійним нападам як самостійного спечіально-кримінологічного напряму.

Ключові слова: генеза, власність, розбій, чуже майно, напад, насильство кримінальна відповідальність.

\section{Becoming and developing responsibility for the robbery in the criminal legislation of Ukraine}

In the article, on the basis of the analysis of historical documents, normative legal acts and practice of activity, the periods of development of criminal responsibility for robbery according to the criterion of legislative consolidation of this concept are highlighted.

An analysis of the historical documents that claimed responsibility for the robbery testified about the distant past of this crime, although the very concept of "robbery" originated around the 10th century. The following conditional periods for the development of criminal responsibility for robbery are outlined: 1) the formation of criminal liability for robbery and its attribution to crimes against property (911 - 1st half of the 16th century); 2) normative improvement of criminal responsibility for robbery (II pol. XVI - 1917); 3) detailing the norms of criminal liability for robbery (1917 - 1990); 4) the modern period of development of criminal responsibility for robbery (1990 - our time). To periodize historical development, the author has chosen the criterion of legislative consolidation of the concept of "robbery", because to establish certain facts only allows the study and comprehensive analysis of official written sources of information, which are historical legal documents. In general, the whole history of the development of responsibility for robbery is a progressive and effective path from robbery as a crime related to murder to robbery as one of the most dangerous crimes against property that affects property relations. At the present stage of development of the Ukrainian state, there are a number of draft laws to amend Art. 187 of the Criminal Code of Ukraine, which are still under discussion and finalization by the Ukrainian legislature.

Based on the results of the study of different approaches to understanding the concept of self-serving violent crime and the scientifictheoretical understanding of the problem of infringement on the property rights and life and health of the person, their prevention, and also taking into account the relevance of this problem, , as an independent special criminological direction.

Keywords: genesis, property, robbery, alien property, assault, violence criminal liability. 